\title{
PENGARUH PERSEPSI KETERLIBATAN ORANG TUA TERHADAP HASIL BELAJAR EKONOMI SISWA
}

\author{
Mohamad Arief Rafsanjani \\ Universitas Islam Riau \\ ariefrafs@gmail.com
}

\begin{abstract}
This research aims to testing Eccles hyphothesis (2005) that the influence of parental involvement on learning outcomes is mediated by selfconcept of students in their academic abilities . The study was conducted on the students of class XI Social SMAN Malang, with 292 as sample. The analysis was conducted using path analysis model causal steps of the Baron and Kenny (1986 ) and Sobel test. The findings in this research suggest that academic self-concept significantly has a function as mediator variable influencing perceptions of parental involvement on student learning outcomes of economy. However, the role of selfconcept variable in academic is partial mediation variable meaning variable that mediate only some of the effects of the perception of parental involvement on learning outcomes .It shows that not only self-concept in academic that became the mediator variable of influence perceptios of parental involvement on learning outcome, but there are other variables that also mediate the causal relationship of those two variables.
\end{abstract}

Keywords: academic self-concept, perception of parental involvement, economic learning outcome

\begin{abstract}
Abstrak: Penelitian ini bertujuan untuk membuktikan dugaan Eccles (2005) yang menyatakan bahwa keterlibatan orang tua terhadap hasil belajar dimediasi oleh konsep diri siswa tentang kemampuan akademiknya. Penelitian dilakukan pada siswa kelas XI IPS SMAN se Kota Malang dengan 292 sampel penelitian. Analisis data menggunakan analisis jalur model causal steps milik Baron \& Kenny (1986) dan uji sobel (Sobel test). Berdasarkan hasil analisis dapat diketahui bahwa konsep diri di bidang akademik berfungsi secara signifikan sebagai variabel mediator pada pengaruh persepsi atas keterlibatan orang tua terhadap hasil belajar ekonomi siswa. Namun peran variabel konsep diri di bidang akademik dalam model penelitian ini merupakan partial mediation variable atau merupakan variabel yang memediasi sebagian dari pengaruh persepsi atas keterlibatan orang tua terhadap hasil belajar. Hal ini menunjukan bahwa tidak hanya konsep diri dibidang akademik yang menjadi variabel mediator dari pengaruh persepsi atas keterlibatan orang tua terhadap hasil belajar, akan tetapi ada variabel lain yang juga memediasi hubungan kausal dari dua variable tersebut.
\end{abstract}

Kata kunci : konsep diri dibidang akademik, persepsi atas keterlibatan orang tua, hasil belajar ekonomi 
Salah satu faktor yang berpengaruh terhadap hasil belajar siswa adalah keterlibatan orang tua. Keterlibatan orang tua mencerminkan sejauh mana orang tua hadir dan menyisipkan diri mereka ke dalam kehidupan anak-anaknya (Gonzalez \& Wolters, 2006). Keterlibatan orangtua juga termasuk komunikasi antara orang tua dan guru (Deslandes et al., 1997); partisipasi orang tua dalam kegiatan-kegiatan sekolah seperti pertemuan orang tua dengan guru (Miedel dan Reynolds, 1999); bantuan yang diberikan orang tua ketika anaknya mendapat Pekerjaan Rumah (PR) dari sekolah (Shumow dan Miller, 2001); serta perilaku orang tua di rumah dan di sekolah dengan tujuan untuk membantu pengalaman belajar anak (Bronfenbrenner, 1986; Galal-El-Dean, 1994). Keterlibatan orang tua memiliki peran penting dalam pencapaian pendidikan anak. Semakin peduli orang tua, akan semakin tinggi bantuan dan dukungan yang diberikan, dan semakin baik pencapaian keberhasilan pendidikan anak.

Penelitian yang telah dilakukan oleh Kim (2002), menemukan adanya hubungan yang signifikan antara keterlibatan orangtua dengan prestasi yang dicapai siswa di sekolah. Van Voorhis (2003) mengemukakan bahwa siswa akan memperoleh capaian akademik yang lebih tinggi ketika orang tua memberikan bantuan dalam pengerjaan tugas-tugas di rumah. Hal yang sama diungkapkan oleh Lamborn et al., (1992) bahwa bantuan orang tua yang diberikan ketika siswa akan mengambil keputusan berhubungan dengan capaian siswa di bidang akademik. Akan tetapi, dalam beberapa penelitian lainnya ditemukan bahwa tidak terdapat bukti signifikan bahwa keterlibatan orang tua berpengaruh langsung terhadap hasil belajar siswa (Bobbett et al., 1995; Keith et al,. 1986; Okpala dan Smith, 2001), dan bahkan terdapat hubungan negatif di antara dua variabel tersebut (Deslandes et al., 1997; Sui-Chu dan Willms, 1996).

Tidak adanya konsistensi hasil temuan-temuan tersebut disinyalir merupakan hasil dari adanya pengaruh tidak langsung keterlibatan orang tua terhadap hasil belajar siswa (El-Fattah, 2006). Tidak ditemukannya bukti pengaruh langsung keterlibatan orang tua terhadap hasil belajar siswa mungkin disebabkan oleh adanya variabel lain yang menjadi mediasi atau perantara di antara dua variabel tersebut (Keith et al., 1986).

Eccles (2005) menduga bahwa pengaruh keterlibatan orang tua terhadap hasil belajar dimediasi oleh konsep diri siswa tentang kemampuan akademiknya. Dugaan ini 
didasarkan pada sebuah model yaitu the expectancy-value model of achievement (Eccles, 1983; Wigfield, 1994), bahwa keinginan untuk menggapai kesuksesan salah satunya dipengaruhi oleh kepercayaan atas kemampuan yang dimiliki yang selanjutnya dikenal dengan istilah konsep diri. Selanjutnya, konsep diri salah satunya dipengaruhi secara langsung oleh keterlibatan orang tua (Eccles dan Wigfield, 2002). Dugaan Eccles (2005) tersebut didasari sebuah argumen bahwa keterlibatan orang tua mempengaruhi kepercayaan diri siswa akan kemampuan yang dimilikinya, yang kemudian berdampak pada hasil pencapaian belajar siswa di sekolah. Akan tetapi dugaan tersebut belum teruji secara empiris karena Eccles (2005) hanya menarik sebuah hipotesis bahwa pengaruh keterlibatan orang tua terhadap hasil belajar dimediasi oleh konsep diri siswa dalam kemampuan akademiknya berdasarkan the expectancy-value model of achievement.

Dari hasil kajian dari penelitian-penelitian yang telah dipaparkan di atas, maka penelitian ini dilakukan untuk menguji secara empiris dugaan Eccles (2005) yang menyatakan bahwa pengaruh keterlibatan orang tua terhadap hasil belajar dimediasi oleh konsep diri siswa tentang kemampuan akademiknya. Peneliti ingin membuktikan dugaan bahwa terdapat pengaruh tidak langsung keterlibatan orang tua terhadap hasil belajar, yaitu dimediasi oleh konsep diri siswa di bidang akademik.

\section{METODE}

Secara umum penelitian ini bertujuan untuk mendeskripsikan dan menganalisis hubungan antara tiga variabel (persepsi atas keterlibatan orang tua, konsep diri di bidang akademik dan hasil belajar ekonomi). Penelitian ini termasuk jenis penelitian eksplanasi (explanatory research). Penelitian dilakukan pada siswa kelas XI IPS SMAN se Kota Malang dengan 292 sampel penelitian. Metode analisis data menggunakan analisis jalur dan dilanjutkan dengan uji sobel (Sobel test).

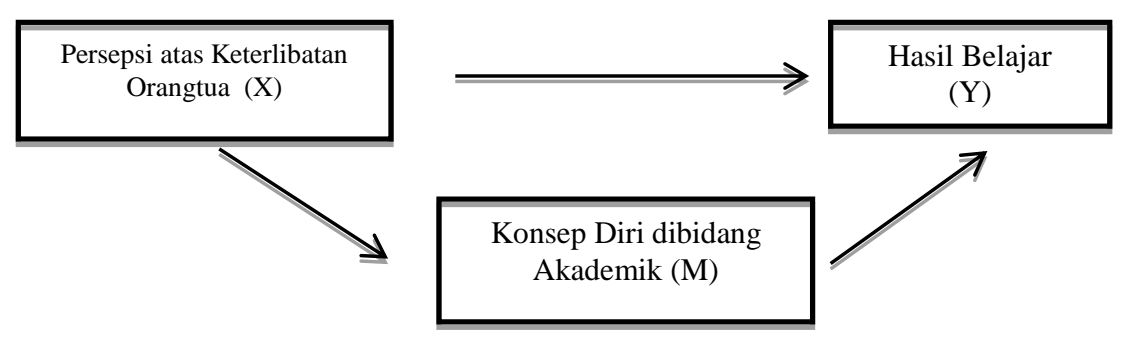

Gambar 1. Hubungan Variabel Bebas dengan Variabel Terikat 


\section{HASIL DAN PEMBAHASAN}

\section{Hasil}

Berdasarkan hasil analisis jalur dengan model causal steps milik Baron \& Kenny (1986) diperoleh hasil sebagai berikut:

Tabel 1. Ringkasan Hasil Uji Model Causal Steps

\begin{tabular}{|c|c|c|c|}
\hline Steps & $\begin{array}{l}\text { Hubungan antar } \\
\text { Variabel }\end{array}$ & Coefficients & Sig \\
\hline Step 1 (jalur $\boldsymbol{c}$ ) & $\mathrm{XY}$ & 0,591 & 0,00 \\
\hline Step 2 (jalur $\boldsymbol{a})$ & $\mathrm{XM}$ & 0,210 & 0,00 \\
\hline Step 3 (jalur $\boldsymbol{b}$ ) & MY & 0,783 & 0,00 \\
\hline Step 4 (jalur $c^{\prime}$ ) & $\begin{array}{l}\text { XY } \\
\text { (dikontrol variable M) }\end{array}$ & 0,427 & 0,00 \\
\hline
\end{tabular}

Dari empat tahapan di atas diketahui bahwa variabel $\mathrm{M}$ (konsep diri dibidang akademik) berfungsi sebagai partial mediation variable atau variabel yang memediasi sebagian dari pengaruh X ke Y. Ketika variabel X dikontrol oleh variabel $\mathrm{M}$, maka pengaruh variabel $\mathrm{X}$ terhadap variabel $\mathrm{Y}$ berkurang, namun masih signifikan memprediksi variabel $\mathrm{Y}\left(\boldsymbol{c}^{\prime}<\boldsymbol{c}\right.$ dan $p$-value $\left.<\alpha\right)$. Dapat disimpulkan bahwa variabel konsep diri di bidang akademik berfungsi sebagai partial mediation variable atau variabel yang memediasi sebagian dari pengaruh persepsi atas keterlibatan orang tua terhadap hasil belajar.

Untuk menguji signifikansi pengaruh tidak langsung digunakan uji Sobel (Sobel Test). Hasil pengujian tampak pada tabel berikut:

Tabel 2. Output Uji Sobel

\begin{tabular}{|c|c|c|c|c|}
\hline Input: & & Test statistic: & Std. Error: & p-value: \\
\hline a 0.210 & Sobel test: & 4.32604791 & 0.03800929 & 0.00001518 \\
\hline$b 0.783$ & Aroian test: & 4.32353537 & 0.03803138 & 0.00001535 \\
\hline$s_{a} 0.048$ & Goodman test: & 4.32856484 & 0.03798719 & 0.00001501 \\
\hline$s_{b} 0.027$ & Reset all & & Calculate & \\
\hline
\end{tabular}

Berdasarkan uji sobel diketahui bahwa indirect effect memiliki $p$-value $<0,01$ yang berarti pengaruh tidak langsung dalam model penelitian ini signifikan. Hal ini menunjukan bahwa hipotesis penelitian ini diterima pada tingkat signifikansi $1 \%$ yang artinya variabel konsep diri di bidang akademik berfungsi secara signifikan sebagai variabel mediator pengaruh persepsi keterlibatan orangtua terhadap hasil 
belajar ekonomi.

\section{Pembahasan}

Dari hasil pengujian menggunakan model causal steps Baron dan Kenny (1986), konsep diri di bidang akademik diketahui merupakan partial mediation variable atau variabel yang memediasi sebagian dari pengaruh persepsi atas keterlibatan orang tua terhadap hasil belajar. Hasil ini menunjukkan bahwa tidak hanya konsep diri di bidang akademik yang menjadi variabel mediator dari pengaruh persepsi atas keterlibatan orang tua terhadap hasil belajar, akan tetapi ada variabel lain yang juga memediasi hubungan kausal dari dua variabel tersebut. Selanjutnya dari hasil uji Sobel diketahui bahwa pengaruh tidak langsung yang terjadi dalam model penelitian ini adalah signifikan. Hal ini membuktikan bahwa konsep diri di bidang akademik berfungsi secara signifikan sebagai variabel mediator dari pengaruh persepsi atas keterlibatan orang tua terhadap hasil belajar.

Hasil penelitian ini menunjukkan bahwa konsep diri di bidang akademik memediasi sebagian (partial mediation) dari pengaruh persepsi atas keterlibatan orang tua terhadap hasil belajar. Hasil penelitian ini menjawab masalah inkonsistensi beberapa penelitian yang menyatakan bahwa tidak terdapat pengaruh signifikan dari persepsi atas keterlibatan orang tua terhadap hasil belajar dan bahkan terdapat hubungan negatif di antara dua variabel tersebut (Bobbett et al., 1995; Keith et al,. 1986; Okpala dan Smith, 2001; Deslandes et al., 1997; Sui-Chu dan Willms, 1996). Inkonsistensi temuan tersebut diduga oleh Keith et al., (1986) dan El-Fattah (2006) akibat adanya variabel lain yang berperan sebagai mediator, dan kemudian terjawab dalam penelitian ini bahwa salah satu variabel yang menjadi mediator tersebut adalah konsep diri di bidang akademik.

Hasil ini juga membuktikan kebenaran dari dugaan Eccles (2005) bahwa pengaruh keterlibatan orang tua terhadap hasil belajar dimediasi oleh konsep diri siswa tentang kemampuan akademiknya. Oleh karena itu hasil penelitian ini juga memperkuat teori the expectancy-value model of achievement yang dikemukakan oleh Eccles (1983) dan Wigfield (1994), yaitu keinginan untuk menggapai kesuksesan salah satunya dipengaruhi oleh kepercayaan atas kemampuan yang dimiliki yang selanjutnya dikenal dengan istilah konsep diri. Selanjutnya, konsep diri salah satunya dipengaruhi oleh keterlibatan orang tua. 
Hasil penelitian ini juga sejalan dengan hasil penelitian sebelumnya yang menemukan bahwa keterlibatan orang tua berpengaruh positif pada konsep diri yang dimiliki siswa (Juang dan Silbereisen's, 2002; Hung, 2005; Grolnick dan Slowiaczek, 1994, Marchant et al., 2001; Gonzalez-DeHass et al., 2005), dan konsep diri siswa secara langsung mempengaruhi prestasi akademik yang dicapai (Guay et al., 2003; Moreano, 2004; Marsh, 2002; Pajares, 2000).

Berdasarkan observasi awal yang dilakukan peneliti diperoleh data bahwa skor hasil belajar rata-rata 81,17 dan jumlah responden penelitian yang lulus atau memenuhi kriteria ketuntasan minimal (KKM) adalah sebanyak 78,42\%. Hasil analisis data deskriptif menunjukkan rata-rata responden memiliki konsep diri di bidang akademik yang tinggi. Hal ini menunjukkan bahwa siswa yang menjadi responden penelitian merasa memiliki kemampuan akademik yang tinggi. Hal ini terlihat pada indicator academic confidence dan academic effort dimana rata-rata siswa (responden penelitian) cukup percaya diri (confidence) bahwa kemampuan akademik yang dimilikinya cukup baik dan merasa memiliki komitmen dan telah berusaha untuk melakukan tugasnya sebagai siswa dengan baik. Dari paparan tersebut terlihat bahwa siswa yang memiliki persepsi atas keterlibatan orang tua yang tinggi akan memiliki konsep diri dibidang akademik yang tinggi juga dan pada akhirnya akan berdampak positif pada hasil belajar yang diperoleh. Hal ini tentu sejalan dengan hasil pengujian hipotesis yang menunjukkan bahwa konsep diri dibidang akademik berfungsi secara signifikan sebagai variabel mediator dari pengaruh persepsi atas keterlibatan orang tua terhadap hasil belajar.

Dapat disimpulkan bahwa hasil pengujian hipotesis dalam penelitian ini membuktikan kebenaran dari dugaan Eccles (2005) bahwa konsep diri dibidang akademik memediasi pengaruh dari persepsi atas keterlibatan orang tua terhadap hasil belajar. Hasil ini juga menjawab dugaan Keith et al., (1986) dan El-Fattah (2006) bahwa ada variabel lain yang menjadi perantara dari pengaruh persepsi atas keterlibatan orang tua terhadap hasil belajar yang kemudian dalam penelitian ini ditemukan bahwa salah satu variabel mediator tersebut adalah konsep diri dibidang akademik. 


\section{SIMPULAN DAN SARAN}

Berdasarkan hasil penelitian diperoleh kesimpulan bahwa variabel konsep diri di bidang akademik berfungsi secara signifikan sebagai variabel mediator dari pengaruh persepsi keterlibatan orangtua terhadap hasil belajar ekonomi pada siswa SMA. Namun peran variabel konsep diri dibidang akademik dalam model penelitian ini merupakan partial mediation variable atau merupakan variabel yang memediasi sebagian dari pengaruh persepsi atas keterlibatan orang tua terhadap hasil belajar, sehingga ada variable lain yang juga turut memediasi hubungan kausal tersebut yang tidak diteliti dalam model ini.

Hasil penelitian ini juga memberikan masukan pada pihak sekolah untuk selalu manjaga komunikasi dan kerjasama dengan orang tua siswa yang salah satunya dengan meningkatkan keterlibatan orang tua siswa dalam kegiatan-kegiatan sekolah dan pengambilan keputusan yang memerlukan masukan dari orang tua siswa sebagai salah satu upaya untuk lebih memahami karakteristik dari masing-masing siswa sehingga dapat memeberikan kontribusi positif dalam upaya peningkatan hasil belajar siswa.

\section{DAFTAR RUJUKAN}

Bobbett, G. C., French, R. L., Achilles, C. M. and Bobbett, N. C.1995. An analysis of Nevada's report cards on high school. Paper presented at the annual meeting of the Mid-South Educational Research Association Annual Meeting, Biloxi, MI

Bronfenbrenner, U. 1986. Ecology of family as a context for human development: Research perspectives. Development Psychology, 22, 723-742.

Deslandes, R., Royer, E., Turcotte, D. and Bertrand, R. 1997. School achievement at the secondary level: Influence of parenting style and parent involvement in schooling. McGill Journal of Education, 32, 191-207.

Eccles, J. S. 2005. Studying the development of learning and task motivation. Learning and Instruction, 15, 161-171.

Eccles, J. S. \& Wigfield A. 2002.Motivational Beliefs, Values, And Goals. Annu. Rev. Psychol. 53:109-32

Eccles, J.S. 1983. Expectancies, values and academic behaviors. In J.T. Spence (Ed.). Achievement and achievement motives (pp.75-146). San Francisco: Freeman 
El-Fattah, Sabry MA. 2006. The relationship among Egyptian adolescents' perception of parental involvement, academic achievement, and achievement goals: A mediational analysis. International Education Journal, 7(4), 499-509

Galal-El-Dean, M. 1994. Parents and teachers effects on high school students' achievement motivation. Unpublished doctoral dissertation, University of Missouri, Missouri, USA.

Gonzalez, A., \& Wolters, C. 2006. The relation between perceived parenting practices andachievement motivation in mathematics. Journal of Research in Childhood Education, 21, 203-217.

Grolnick, W. and Slowiaczek, M. 1994. Parents' involvement in children's schooling: A multidimensional conceptualization and motivational model. Child Development, 65, 237-252.

Guay, F., Marsh, H. W., \& Boivin, M. 2003. Academic self-concept and achievement: Developmental perspective on their causal ordering. Journal of Educational Psychology, 95, 124-136.

Hung, Chih-Lun. 2005. Family Background, Parental Involvement and Environmental Influences on Taiwanese Children. The Alberta Journal of Educational Research. 51(3), 261-276

Juang, L.P., \& Silbereisen, R.K. 2002. The relationship between adolescent academic capability beliefs, parenting, and school grades. Journal of Adolescence, 25,318.

Keith, T. Z., Reimers, T. M., Fehrmann, P. G., Pottebaum, S. M. and Aubey, L. W. 1986. Parental involvement, homework, and TV time: Direct and indirect effects on high school achievement. Journal of Educational Psychology, 78, 373-380.

Kim, Eunjung. 2002. The relationship between parental involvement and children's educational achievement in the Korean immigrant family.Journal of Comparative Family Studies. 33.4 p529

Lamborn, S., Brown, B., Mounts, N. and Steinberg, L. 1992. Putting school in perspective: The influence of family, peers, extracurricular participation, and part-time work on academic engagement. In F. Newmann (Ed.), Student Engagement and Achievement in American Secondary Schools(pp. 153-181). New York: Teachers College.

Marchant, G.J., Paulson, S.E., \& Rothlisberg, B.A. 2001. Relations of middle schoolstudents' perceptions of family and school contexts with academic achievement. Psychology in the Schools, 38(6), 505-519. 
Marsh, H. W., Ellis, L., \& Craven, R. G. 2002. How do pre-school children feel about themselves? Unravelling measurement and multidimensional self-concept structure. Developmental Psychology, 38,376-393.

Miedel, W. T. and Reynolds, A. J. 1999. Parent involvement in early intervention for disadvantaged children: Does it matter? Journal of School Psychology, 37, $379-402$.

Moreano, Giovanna. 2004. The Relationship Between Academic Self-Concept, Causal Attribution For Success and Failure, and Academic Achievement in PreAdolescents. Dalam H.W. Marsh, J. Baumert, G.E. Richards, dan U. Trautwein (Eds.), Self-Concept, Motivation and Identity: Where to from here? (hlm. Proceedings of The Third Intenational Biennial SELF Research Conference. Berlin: Max Planck Institute for Human Development.

Okpala, C. O., Okpala, A. O. and Smith, F. E. 2001. Parental involvement, instructional expenditures, family socioeconomic attributes, and student achievement. Journal of Educational Research, 95, 110-115.

Shumow, L., \& Miller, J. D. 2001. Parents' at-home and at-school academic involvement with young adolescents. Journal of Early Ad-olescence, 21,68-91.

Sui-Chu, E. and Willms, J. D. 1996. Effects of parental involvement on eighth grade achievement. Sociology of Education, 69, 126-141.

Van Voorhis, F. L. 2003. Interactive homework in middle school: Effects on family involvement and science achievement. Journal of Educational Research, 96, 323-338.

Wigfield, A. 1994. Expectancy-value theory of achievement motivation: A developmental perspective. Educational Psychology Review, 6,49-78. 